\title{
Serum Diphenylamine Reaction in Rheumatic Disease of Children
}

\author{
By \\ Tooru Nakao and Toshio Nitta \\ From the Department of Pediatrics, Aomori Prefectural Central \\ Hospital; Pediatrician-in-Chief: Dr. T. Nakao
}

(Received for publication, August 18, 1961)

The substance in serum which reacts with diphenylamine to give a purple color has not been identified. Niazi and State ${ }^{1)}$ reported the serum level of a substance which reacts with diphenylamine was elevated in several disease, including rheumatic fever. Ayala et al. ${ }^{2}$ and Coburn et al. ${ }^{3)}$ observed a relation between the intensity of reaction and the degree of rheumatic activity.

In the present paper we shall report serum diphenylamine reaction in rheumatic disease of children.

\section{EXPERIMENTAL}

\section{MATERIALS AND METHOD}

The children subjected to this investigation were the patients who were admitted to our Hospital in 1957.

We employed the semimicro procedure described by Ayala et al. ${ }^{2)}$ According to this procedure, $5 \mathrm{cc}$ of $5 \%$ trichloroacetic acid solution was added slowly with gentle shaking to $0.2 \mathrm{cc}$ of serum in a test tube. The tube was then placed in a boiling water bath and kept for exactly 20 minutes and then immediately cooled by immersion in iced water. The tube was kept stoppered during hydrolysis. The hydrolyzate was filtrated and $1.5 \mathrm{cc}$ of the clear filtrate was transferred to a test tube to which were added 3 cc of Dische's diphenylamine reagent. The tube was then immersed in a boiling water bath and kept in it for exactly 30 minutes. After removal from the bath the tube was cooled in iced water and then allowed to come down to room temperature. The optical density was read in Model IV Elma spectrophotometer at $530 \mathrm{~m} \mu$. Two blanks were required. One blank consisted of $5 \%$ trichloroacetic acid and the standard reagent in the same proportion as used for the reaction. This blank was used to establish the zero optical density setting of the spectrophotometer. The second blank consisted of $1.5 \mathrm{cc}$ of serum hydrolyzate and $3.0 \mathrm{cc}$ of acetic sulfuric acid mixture without diphenylamine. The second blank must be prepared separately for

中屠亭, 新田敏雄 
each serum sample. The optical density figure of this blank was to be subtracted from that of the corresponding serum sample giving a purple color reaction. The values were reported in Color Units $\left(1.000 \times \log ^{10} / \mathrm{r}\right)$.

\section{RESULTS}

Results are given in Table I. Serum diphenylamine values were obtained from 11 healthy children, and the mean in this group was 155 C.U. In 14 rheumatic children who had 3 rheumatoid arthritis and 11 rheumatic fever, 33 determinations were made and the mean in this group was 264 C.U. These were remarkably larger figures than those in healthy children.

TABLE I. Results of Serum Diphenylamine Reaction in Healthy, Rheumatic and Nonrheumatic Children.

\begin{tabular}{|c|c|c|c|c|}
\hline & \multirow{2}{*}{$\begin{array}{c}\text { No. of } \\
\text { cases }\end{array}$} & \multirow{2}{*}{$\begin{array}{l}\text { No. of } \\
\text { determi- } \\
\text { nations }\end{array}$} & \multicolumn{2}{|c|}{ Serum diphenylamine values } \\
\hline & & & Range of changes & Mean \\
\hline Healthy children & 11 & 11 & $86-232$ & 155 \\
\hline $\begin{array}{l}\text { Rheumatic children } \\
\text { Rheumatoid arthritis } \\
\text { Rheumatic fever }\end{array}$ & $\begin{array}{r}3 \\
11\end{array}$ & $\begin{array}{l}12 \\
21\end{array}$ & $\begin{array}{l}166-437 \\
100-390\end{array}$ & $\begin{array}{l}301 \\
243\end{array}$ \\
\hline Total & 14 & 33 & $100-437$ & 264 \\
\hline $\begin{array}{l}\text { Nonrheumatic children } \\
\text { Acute infectious diseases } \\
\text { Chronic infectious diseases } \\
\text { Renal diseases } \\
\text { Diseases of liver and bile duct } \\
\text { Diseases of the blood } \\
\text { Cyclic vomiting }\end{array}$ & $\begin{array}{r}15 \\
9 \\
9 \\
3 \\
2 \\
1\end{array}$ & $\begin{array}{r}15 \\
16 \\
11 \\
5 \\
3 \\
2\end{array}$ & $\begin{array}{r}152-428 \\
99-405 \\
120-540 \\
110-417 \\
133-332 \\
293-405\end{array}$ & $\begin{array}{l}249 \\
184 \\
246 \\
236 \\
221 \\
349\end{array}$ \\
\hline Total & 40 & 52 & $99-540$ & 243 \\
\hline
\end{tabular}

In nonrheumatic children, the mean of serum diphenylamine values was 243 C.U. But some of these nonrheumatic cases showed very high Color Units; two cases of scarlet fever were of 428 C.U. and 338 C.U., a case of severe pneumonia of 410 C.U., a case of cyclic vomiting of 405 C.U., a case of uremia of 540 C.U., a case of miliary tuberculosis of 405 C.U. and a case of infectious hepatitis of 417 C.U. These figures were markedly large. If only the mean in this nonrheumatic group is shown, the figure is not so different from those in rheumatic children, so that one might be misled to a false conclusion that rheumatic and nonrheumatic groups are about of the same C.U.

In rheumatic children who were determined repeatedly during the illness, there was a close parallelism between the serum diphenylamine values and the 


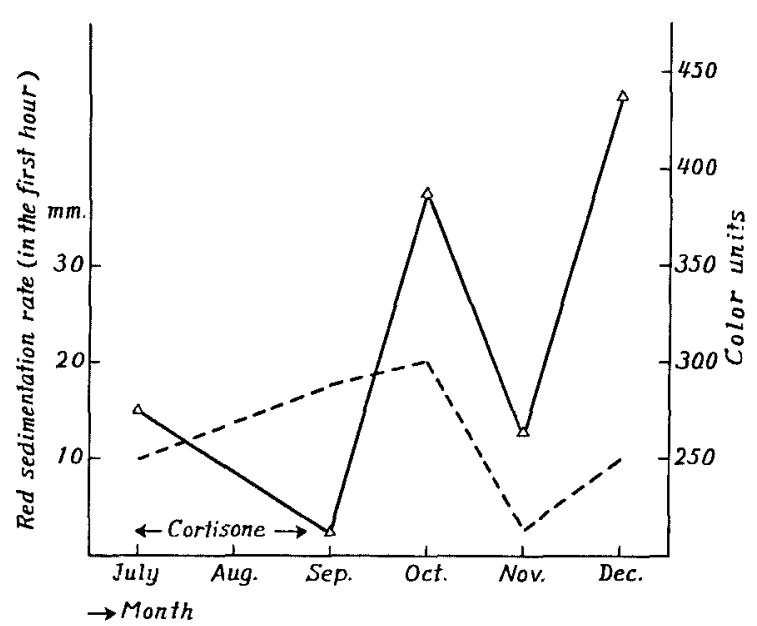

Fig. 1. Relation between diphenylamine reaction and red sedimentation rate. Case 1. 7 years, male, rheumatoid arthritis.

$\Delta-\Delta \ldots \ldots$ serum diphenylamine value

......... red sedimentation rate

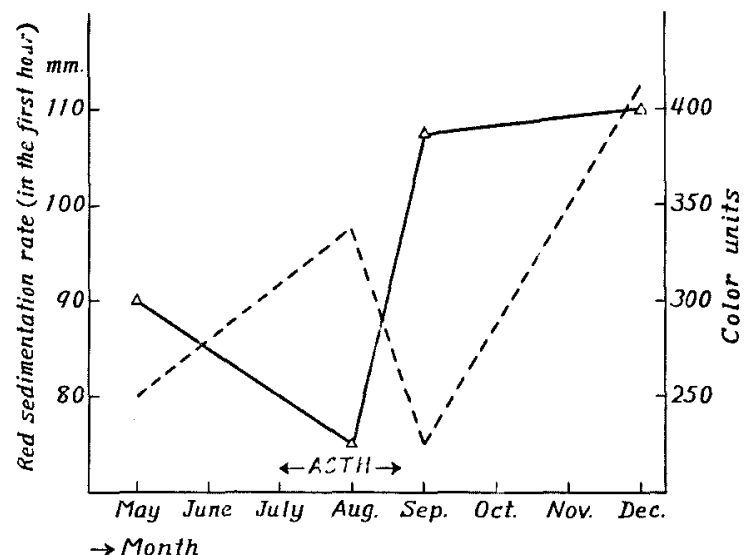

Fig. 2. Relation between diphenylamine reaction and red sedimentation rate. Case 2. 12 years, male, rheumatoid arthritis. $\Delta-\Delta \ldots \ldots$ serum diphenylamine value ......... red sedimentation rate

red sedimentation rate. This relation is shown in six illustrative cases in Figs. 1-6. In rheumatoid arthritis, serum diphenylamine values decreased by steroid therapy (Case 1). There was, in general, a close relation between the severity of rheumatic process and the intensity of diphenylamine reaction. 


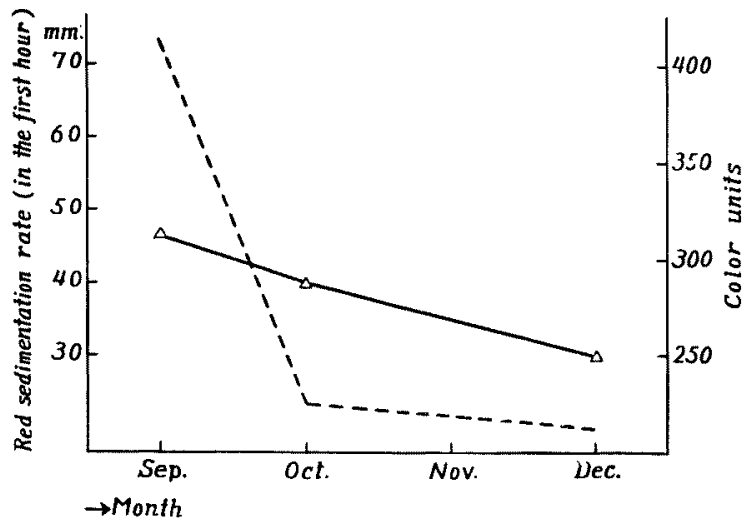

Fig. 3. Relation between diphenylamine reaction and red sedimentation rate. Case 3. 12 years, female, rheumatoid arthritis with heart disease.

$\triangle-\triangle \ldots \ldots \ldots$ serum diphenylamine value

$\ldots \ldots$ red sedimentation rate

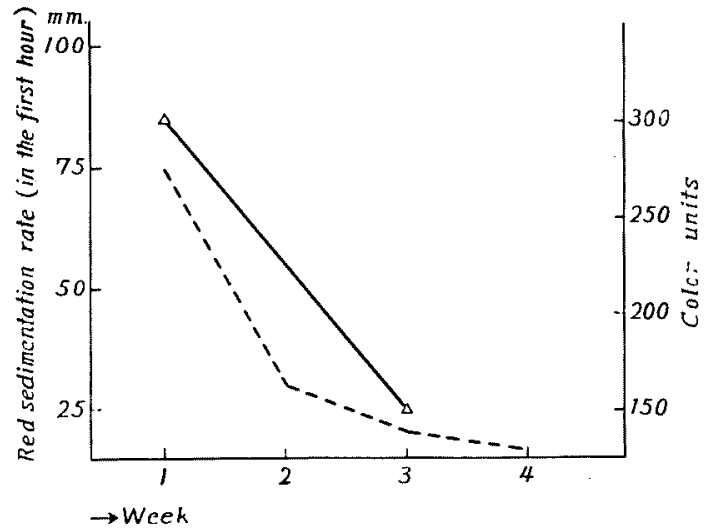

Fig. 4. Relation between diphenylamine reaction and red sedimentation rate. Case 4.12 years, female, rheumatic fever.

$\Delta-\triangle \ldots \ldots$ serum diphenylamine value

$\ldots \ldots$ red sedimentation rate

\section{CONCLUSIONS}

Serum diphenylamine reaction was carried out in 11 healthy, 14 rheumatic and 40 nonrheumatic children. In rheumatic children, there was remarkable increase of serum diphenylamine values compared with healthy children, but in several cases of nonrheumatic diseases, serum diphenylamine values were also markedly increased. Generally the diphenylamine reaction ran parallel with the 


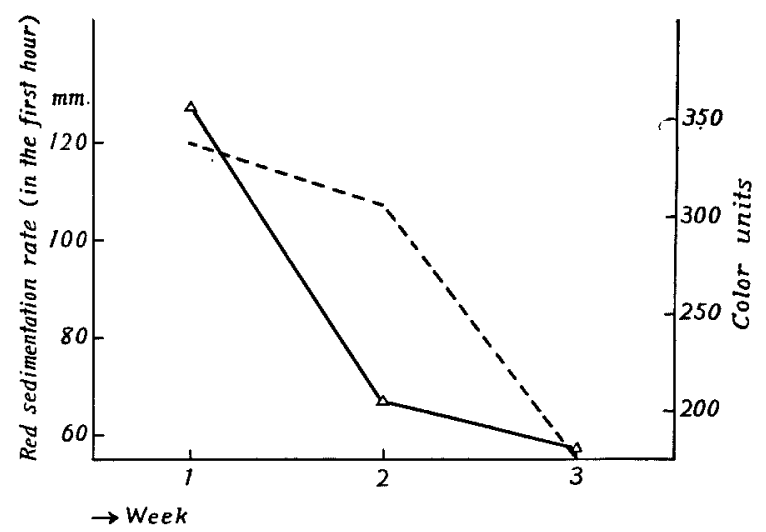

Fig. 5. Relation between diphenylamine reaction and red sedimentation rate. Case 5. 9 years, male, rheumatic fever.

$\Delta-\Delta \ldots \ldots$ serum diphenylamine value

$\ldots . . . . \ldots$ red sedimentation rate

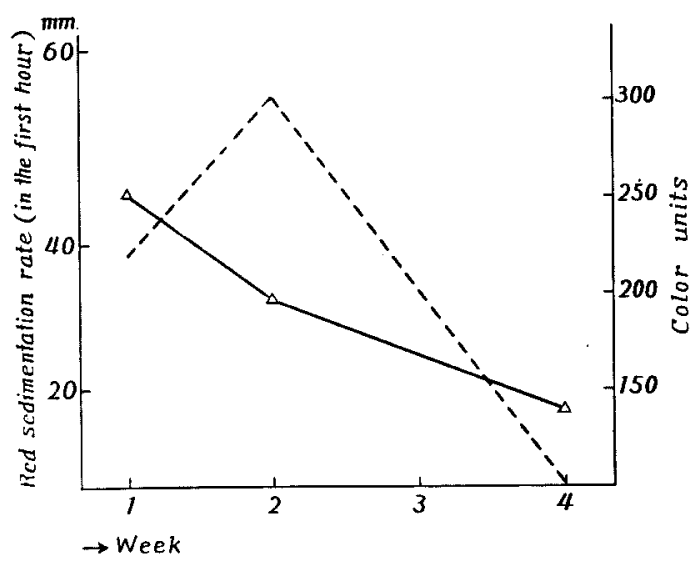

Fig. 6. Relation between diphenylamine reaction and red sedimentation rate. Case 6. 8 years, female, rheumatic fever.

$\Delta-\Delta \ldots \ldots$ serum diphenylamine value

$\ldots . . . . .$. red sedimentation rate

red sedimentation rate in rheumatic disease of children. The reaction, indeed, is not specific for rheumatic disease of children and of almost no help in differential diagnosis of the disease, but, as Coburn et al. ${ }^{3)}$ stated, it will be helpful in estimating the degree of rheumatic activity as well as in evaluating the effectualness of therapeutic agents. 


\section{References}

1) Niazi, S. \& State, D., Cancer Res., 1948, 8, 653.

2) Ayala, W. et al., J. Clin. Invest., 1951, 30, 781.

3) Coburn, A.F. et al., Arch. Int. Med., 1953, 92, 185. 